\title{
Generation Y Attitudes towards Shopping: A Comparison of the Czech Republic and Slovakia
}

- Klapilová Krbová Petra

\begin{abstract}
This paper presents the results of a study focused on Generation Y (born between 1980 and 2000) behavior in two neighboring European countries, the Czech Republic and Slovakia. This article identifies and describes basic characteristics of this generation's general behavior as well as defines specifics of their shopping behavior by examining their attitudes towards retailers, brands, sales and discount offers. The sample consisted of 380 respondents: 162 from Slovakia and 218 from the Czech Republic. Results of the analysis indicate that shopping is perceived as an entertaining and pleasurable leisure activity. A particular product is chosen before the shopping place. Approximately two-thirds of the respondents search for information online, but quite a large percentage prefer both offline searching and purchasing. Brands are considered to be the symbols and guarantors of quality, but also uselessly expensive. Finally, a positive attitude towards sales and discount offers was observed.
\end{abstract}

Keywords: shopping attitudes, brick-and-mortar stores, factor analysis, Generation Y, online shopping behavior, Czech Republic, Slovakia

JEL Classification: M31, M39

\section{INTRODUCTION}

Generation Y, so called Millenials, is a specific cohort of people who usually have similar characteristics and features. A cohort is defined by particular boundaries, i.e. years of birth or age. Generation Y comprises people born between years 1977-2000 (Noble, Haytko \& Phillips, 2009). Other authors shorten this interval to years 1980-1994 (Bednall, Valos, Adam \& McLeod, 2012). In this paper Generation Y consists of people born between 1980 and 2000.

Specific characteristics and features can be found in many fields of interest, e.g. lifestyle, choice of education or job and also in shopping behavior. These specifics can lead to a need of collecting information about generations in general. Generation Y possess a great purchase power and therefore it has become a crucial segment for marketers (Sox, Kline and Crews, 2014). Members of this generation are able to spend their money quickly (Parment, 2013; Pentecost \& Andrews, 2010; Mandhlazi et al., 2013). Understanding differences of one generation from another can lead to creating the effective marketing strategies (Parment, 2013).

The main objective of this paper is to (1) specify general features of Generation Y behavior, (2) describe general perceptions of shopping by Generation Y and (3) specify attitudes of Generation $Y$ to shopping process, branded products, sales and discounts. In an original research many other issues were included (e.g. information sources used by Generation Y), but they are not the concern of this paper. 
The research was conducted in the Czech Republic and Slovakia in autumn and winter 2014. Generation Y members born between 1980 and 2000 served as a population. The sample comprised 380 respondents, 162 from Slovak Republic and 218 from the Czech Republic.

\section{THEORETICAL BACKGROUND}

Generation $\mathrm{Y}$ is the second largest generational cohort growing up in a world infused with brands (Martin and Turley, 2004). It has been socialized in a materialistic society (Bakewell and Mitchell, 2006). The purchasing power of Generation $\mathrm{Y}$ has an unprecedented impact on the economy and this generational cohort is highly active in the marketplace (Noble, Haytko \& Phillips, 2009).

Generation Y in general does not like to read and comprehend monotonous textual information. This assumption can be completely applied especially for one group of Generation Y (collegeaged students) which consists of mostly visual learners (Weiler, 2005). If it is necessary to read, electronic platforms are more preferred (Jain \& Pant, 2012). Communication should also contain those visual stimuli such as screencasting videos and images (Carr and Ly, 2009). Generation Y individuals are able to pay attention for a shorter period of time; they easily get bored and often multitask. The information sources therefore should be instant (Jain and Pant, 2012).

In the retail environment, this can be used in various ways. Small changes in presentation of merchandise can lead to higher attention of this group, e.g. grouping of merchandise by colors or regular changes in the shop windows. The interest about merchandise can then probably rise.

Generation $\mathrm{Y}$ is one of the first generations to know technology and the internet from a very early age. They consider modern technologies as inevitable for their life and also use them on a daily basis. These people very often belong among innovators or early adopters according to the Innovation Adoption Lifecycle Theory (Mangold \& Smith, 2012).

Generation Y members are significantly more likely than older generations to create blogs, download music and play online games. The usage of the internet is much wider; they search for health information, conduct job research, use online banking and make accommodation reservations when they travel (Djamasbi, Siegel \& Tullis, 2010).

Generation Y individuals are very savvy in the usage of new technologies and more involved in online behavior, e.g. on social networks or in online shops. They use social networks in a high volume. These networks have a strong impact on their lives as social media embrace the nature of interactive online media (Nusair et al., 2013).

Affective commitment to social media websites, e.g. by Nusair et al. (2013) in the travel industry, can only be created and maintained if Generation Y identifies some benefits on the site. This may include better knowledge of the destination, belonging to the group of people with the same interests and having fun using the tools. The user has to recognize the value-relevance (Nusair et al., 2013).

Generation $\mathrm{Y}$ is a strong determinant of online purchasing behavior and it contributes to the highest percentage of online purchasing (Dhanapal, Vashu \& Subramaniam 2015). Their wide 
and prevalent usage of the internet, combined with their distinct position of growing up exposed to advanced technology, makes Generation Y a unique target market (Djamasbi, Siegel \& Tullis, 2010).

As well as new technologies and internet, also new retail formats emergence is nothing new and surprising to Generation Y. Its members are used to shop in supermarkets, shopping centers, and convenience stores or category killers (Brosdahl \& Carpenter, 2012).

Shopping is considered to be mostly a leisure activity and entertainment. Browsing in the shopping center is more important than purchase itself (Bakewell and Mitchell, 2006). Time spent in the shopping center by Generation $Y$ is higher than by other generations (Gilboa \& VilnaiYavetz, 2010). Generation Y also enjoys shopping significantly more than other generational cohorts, visit higher number of stores before final purchase and prefer online retailers more (Brosdahl \& Carpenter, 2011).

Time in the shopping center is spent with other people like family and friends and as an addition to the purchase also entertainment facilities and restaurants are visited (Gilboa \& Vilnai-Yavetz, 2010). The evaluation of a specific shopping place is better when it is airy, safe and accessible and offers a good tenant mix and atmosphere (Haytko \& Baker, 2004).

Brand awareness is very high in Generation Y cohort (Noble, Haytko \& Phillips, 2009) in contrast with loyalty. It is hard to persuade this generation to be loyal. Switching brands is other typical feature which fits a low loyalty level (Jain \& Pant, 2012).

In the field of luxury brands, perceived brand leadership is more important than its uniqueness. Successful brands should be trendy, visionary and up-to-date. Consequently, Generation Y perceives those brands as more luxury than brands that are unique, original and creative (Miller \& Mils, 2012). Retail patronage and product purchases are influenced for example by brand personality, fashion knowledge and seeking of value or comfort of brands. Recognition of trends in the fashion market is typical for this generation, especially when it comes to the college-aged students (Noble, Haytko \& Phillips, 2009). Generations Y talks more than twice often about brands in their conversations than other generations (Bergh \& Behrer, 2011).

Higher attraction and consumption of conspicuous products and services is typical for younger generations. They use them not only because of their high quality, but also due to social standing (Phau \& Cheong, 2009; O’Cass \& Siahtiri, 2013). According to Eastman and Liu (2012) Generation $\mathrm{Y}$ has the highest level of motivation to consume for status compared to Generation X and Baby boomers.

On the other hand, sales and discounts are very welcomed by Generation Y. Using a coupon by purchase is no shame. The main aim of coupons is to save money. Building a relationship with retailer is not the main objective (Ballard et al., 2013).

The process of decision making differs in case of product and retailer (shopping place). The choice of a product is more emotional while shopping place is chosen more on a rational level. Generation Y also decides at first about a product, after then decision about the shopping place follows. This confirms a low loyalty level, especially to the retailer (Parment, 2013). 
Significant others can influence the final choice of both a product and a retailer because Generation Y individuals perceive a social risk very strongly (Parment, 2013). Therefore they often make purchases together with their family and friends. It enables them to watch their reactions to intended purchase (Gilboa \& Vilnai-Yavetz, 2010). Significant others have a very strong influence on the decision (Bergh \& Behrer, 2011). This behavior also indicates that basic reference groups are also used as the sources of information. The opinions of family members and friends are the most used offline source (Varutti, 2011; OMG, 2011).

According to Horáková (2015) in a category of college-aged students in the Czech Republic, the highest share on expenditures of income in a category of students with lower disposable income goes to purchase of food and beverages, transport services and clothing and footwear. Unlike students with higher disposable income spend most money for housing, food and beverages and transport services (Horáková, 2015). Income earned by Generation Y individuals is less often used for purchase of conspicuous goods and services than pocket money (Kim \& Jang, 2014).

\section{RESEARCH METHOD}

\subsection{Research Aim}

The main aim of this research was to describe specific features of Generation Y attitudes to shopping in general. Some partial aims were also set as follows (1) to specify general features of Generation Y behavior, (2) to describe general perceptions of shopping by Generation Y and (3) to specify attitudes of Generation Y to shopping process, branded products, sales and discounts.

The original research was also focused on some other issues which are not part of this article like information sources used before purchase or factors influencing store selection.

\subsection{Data Collection}

Data were collected due to the availability of the respondents by written and online questioning. The written questioning served as a complement to the online survey. No differences between samples were observed. Because the research problem was very complex, the questionnaire was decided to be longer than commonly.

Data were collected from the end of October 2014 to January 2015.

An online questionnaire was created by Google Documents and spread by personal contacts, email addresses and by social networks. Written questionnaire was spread in particular secondary schools in Moravian-Silesian Region in the Czech Republic and Region of Zilina in Slovakia.

People born between years 1980 and 2000 served as s population for this research. The sample consisted of 380 respondents (218 from the Czech Republic and 162 from Slovakia). Judgmental sampling was used for the specification of the sample. Final structure of the sample is available in Tab. 1. 
Tab. 1 - Structure of the Sample. Source: Author's Own.

\begin{tabular}{|c|l|c|c|c|}
\cline { 3 - 5 } \multicolumn{2}{c|}{} & Count & $\%$ & Mean \\
\hline \multirow{3}{*}{ Gender } & Men & 159 & $42 \%$ & \\
\cline { 2 - 5 } & Women & 221 & $58 \%$ & \\
\hline \multirow{3}{*}{ Education } & The Czech Republic & 218 & $57 \%$ & \\
\cline { 2 - 5 } & The Slovak Republic & 162 & $43 \%$ & \\
\cline { 2 - 5 } & Primary or apprentice school & 131 & $35 \%$ & \\
\cline { 2 - 5 } & High school & 134 & $35 \%$ & \\
\cline { 2 - 5 } Age & University & 115 & $30 \%$ & \\
\hline \multirow{2}{*}{ Age } & & & 22 \\
\hline
\end{tabular}

The basic type of scale used in the questionnaire was a Likert-type scale where 1 meant strong agreement and 7 meant strong disagreement.

Analysis was conducted with the usage of SPSS 21.0 and Microsoft Excel software. In this paper especially basic descriptive statistics were used, but also a factor analysis in order to detailed analysis of attitudes. Exploratory factor analysis, especially principal component analysis was used to reduce dimensions in various variables. Extraction was based on Eigenvalue greater than 1 and factors were rotated according to Varimax procedure.

\section{RESULTS}

\subsection{General Features of Generation Y Behavior}

The evaluation of several statements concerned on general behavior of Generation $\mathrm{Y}$ on the 7-point Likert-type scale can indicate the basis from which general attitudes to shopping can come.

Generation $\mathrm{Y}$ individuals living in the Czech Republic and Slovakia differ significantly (sig.=0.004) in the only one parameter (Almost all decisions are made by myself), but this difference in not very strong $(\eta=0.147)$. Slovaks claimed a higher inclination to decide individually than Czechs (mean value 2.5 to 2.9). For the results see Tab. 2. In general this statement had the highest level of agreement (mean=2.7). People in this generation are more individuals than members of a team.

Tab. 2 - General Features of Behavior in the Czech Republic and Slovakia (Mean Values). Source: Author's Own.

\begin{tabular}{|l|c|c|c|}
\hline $\begin{array}{l}\text { General features } \\
(1=\text { strongly agree, } 7=\text { strongly disagree })\end{array}$ & $\begin{array}{c}\text { The Czech } \\
\text { Republic }\end{array}$ & $\begin{array}{c}\text { The Slovak } \\
\text { Republic }\end{array}$ & Total \\
\hline Almost all decisions are made by myself. & 2.9 & 2.5 & 2.7 \\
\hline $\begin{array}{l}\text { Good education is the basis for further success } \\
\text { in life. }\end{array}$ & 2.8 & 2.9 & 2.9 \\
\hline
\end{tabular}




\begin{tabular}{|l|c|c|c|}
\hline $\begin{array}{l}\text { When I want to connect with my friends, I text } \\
\text { them on Facebook. }\end{array}$ & 2.9 & 2.8 & 2.9 \\
\hline $\begin{array}{l}\text { I listen to music mainly on my MP3 od cell } \\
\text { phone. }\end{array}$ & 3.3 & 2.9 & 3.1 \\
\hline I use social networks very often. & 3.1 & 3.2 & 3.1 \\
\hline $\begin{array}{l}\text { If I need information, I use my smartphone the } \\
\text { most }\end{array}$ & 3.6 & 3.8 & 3.7 \\
\hline I check my Facebook profile constantly. & 4.1 & 4.4 & 4.2 \\
\hline $\begin{array}{l}\text { When I am not online, I feel cut off from infor- } \\
\text { mation. }\end{array}$ & 4.3 & 4.6 & 4.4 \\
\hline $\begin{array}{l}\text { I do not care about new technologies that } \\
\text { emerge on the market. }\end{array}$ & 4.8 & 4.8 & 4.8 \\
\hline $\begin{array}{l}\text { When I am at work or outdoor, I am constantly } \\
\text { online. }\end{array}$ & 5.1 & 5.4 & 5.8 \\
\hline $\begin{array}{l}\text { I always immediately download new app for my } \\
\text { cell phone. }\end{array}$ & 4.6 & 5.8 \\
\hline
\end{tabular}

Generation Y individuals did not confirm the assumption of constant presence in online environment, downloading new launched applications to the cell phone immediately or the feeling of cutting off from the sources of information when they are not online. The result is that this generation is not strictly addicted to online world. They in general do not feel a necessity to be online everywhere, every time and in every possible situation.

On the other hand, they are really interested in new technologies emerging on the market and use their cell phones on a daily basis also for other reason than calling or texting. Facebook as the most popular social network is used by them for posting messages to friends and communication. Generation Y individuals consider good education as a basis for their success in a future life.

Statistically significant differences in the evaluation of statements by gender were observed only in three occasions. The interest of men in new technologies emerging on the market is higher $($ mean $=5)$ than in the group of women (mean=4.6). The strength of dependence is low $(\eta=0.109$, sig. $=0.034)$. This result can be confirmed by the evaluation of other statements.

Women much rarely download new applications to their cell phones (mean=5.5) than men (mean=4.8). The difference is again statistically significant on the $5 \%$ level of significance and the strength of dependence is again low $(\eta=0.200$, sig. $=0.000)$. Men less strongly disagree with the statement 'When I am at work or outdoor, I am constantly online' (mean=4.4) than women (mean=5.0). This last dependence is also low $(\eta=0.136$. sig $=0.008)$.

For detailed insight, a factor analysis was used to examine the statements. Factor analysis is applicable because of the results of Kaiser-Meyer-Olkin measure of sampling adequacy (KMO measure $=0.662$ ) and significance of Bartlett's test of sphericity (sig. $=0.000$ ). Statements were divided into 4 groups (see Tab. 3). Statements within each group were evaluated similarly. 
Tab. 3 - Factor Analysis of General Attitudes of Generation Y. Source: Author's Own.

\begin{tabular}{|l|c|c|c|c|}
\hline Rotated Component Matrix & 1 & 2 & 3 & 4 \\
\hline I use social networks very often. & 0.843 & & & \\
\hline $\begin{array}{l}\text { When I want to connect with my friends, } \\
\text { I text them on Facebook. }\end{array}$ & 0.764 & & & \\
\hline I check my Facebook profile constantly. & 0.752 & & & \\
\hline When I am not online, I feel cut off from information. & 0.526 & & & \\
\hline I always immediately download new app for my cell phone. & & 0.769 & & \\
\hline When I am at work or outdoor, I am constantly online. & & 0.731 & & \\
\hline If I need information, I use my smartphone the most. & & 0.69 & & \\
\hline Almost all decisions are made by me. & & & 0.66 & \\
\hline I listen to music mainly on my MP3 or cell phone. & & & 0.595 & \\
\hline Good education is the basis for further success in life. & & & 0.542 & \\
\hline $\begin{array}{l}\text { I do not care about new technologies that emerge on the } \\
\text { market. }\end{array}$ & & & & 0.964 \\
\hline
\end{tabular}

The first factor can be named as 'Always online' regarding to the statements which were evaluated similarly. The usage of social media has very high frequency. Social networks are used as channels for communication with the social environment and especially Facebook is checked almost constantly. Without being online, the feeling of cutting off from the information is present.

The second factor 'Online information' consists of statements which indicate the willingness to search information online and the stress Generation Y can feel when online connection is not available anytime. The inclination to download all new applications to the mobile phone is high. The mobile phone is used to download information. No matter where (at work or outdoor), the need to be online is perceived.

The third new factor can be named as 'Individuality'. It comprises statements referring to the process of making decisions by Generation $\mathrm{Y}$ and the consciousness of the importance of good education.

The last factor refers to the usage of new technologies which emerge on the market. It consists of the only one statement.

These results could be further used for segmentation of Generation Y according to their general attitudes to new technologies and online environment.

\subsection{General Perceptions of Shopping by Generation $Y$}

The perception of shopping as an activity is well-defined by Generation Y. All the mean values oscillate around the middle of the scale (7-point Likert-type scale). All expressions, except of the only one (Browsing versus targeting), are evaluated below this value (see Tab. 4).

Generation Y perceives shopping as necessary for their living and more as a pleasure and fun. Members of this group shop with enthusiasm, but they have a little doubt about relaxing impact of shopping on their frame of mind. 
Tab. 4 - Perception of Shopping by Generation Y (Mean Values). Source: Author's Own.

\begin{tabular}{|l|c|c|c|c|c|}
\cline { 2 - 6 } \multicolumn{1}{l|}{} & Total mean & $\begin{array}{c}\text { The Czech } \\
\text { Republic }\end{array}$ & $\begin{array}{c}\text { The Slovak } \\
\text { Republic }\end{array}$ & Men & Women \\
\hline $\begin{array}{l}\text { Necessity versus } \\
\text { uselessness. }\end{array}$ & 3.3 & 3.3 & 3.3 & 3.3 & 3.3 \\
\hline Fun versus boredom. & 3.3 & 3.3 & 3.2 & 4.0 & 2.8 \\
\hline Pleasure versus duty. & 3.4 & 3.4 & 3.4 & 4.2 & 2.9 \\
\hline $\begin{array}{l}\text { Enthusiasm versus } \\
\text { satiety. }\end{array}$ & 3.5 & 3.5 & 3.4 & 4.1 & 3.0 \\
\hline Relax versus struggle. & 3.8 & 3.8 & 3.7 & 4.4 & 3.3 \\
\hline $\begin{array}{l}\text { Browsing versus } \\
\text { targeting. }\end{array}$ & 4.7 & 4.7 & 4.8 & 5.1 & 4.5 \\
\hline
\end{tabular}

Browsing in the shop is less used; they more go straight to the product or service they would like to purchase. This can indicate that Generation Y individuals spend more time by 'preparation' before purchase and search more information, so they do not have to browse directly in the shop to find an appropriate product.

The opinions between the countries were very similar, no significant differences were found. In regard to gender, almost all statements (except or the last one in Tab. 4) were evaluated differently by men and women and this differences were statistically significant. The strength of all dependences is higher than 0.3 , which indicates the medium level of dependence. Women in general perceive shopping more as fun $(\eta=0.352$, sig. $=0.000)$, pleasure $(\eta=0.351$, sig. $=0.000)$ and relax $(\eta=0.309$, sig. $=0.000)$. They shop more with enthusiasm $(\eta=0.323$, sig. $=0.000)$.

\subsection{Preference of Online and Offline Shopping Place}

Lightly more than $80 \%$ of Generation Y members choose at first an appropriate product they would like to buy and only then they start to think about a suitable shopping place (see Tab. 5). This is a general attitude which can be related to both countries and also to both genders. No statistically significant differences in the answers of these groups were found.

Tab. 5 - Information Seeking and Place of Purchase. Source: Author's Own.

\begin{tabular}{|l|c|c|}
\hline Process of choosing product/shopping place & Count & $\%$ \\
\hline I choose a product first then the shopping place. & 305 & $80 \%$ \\
\hline I choose a shopping place first then a particular product. & 75 & $20 \%$ \\
\hline Process of seeking information and selecting shopping place & Count & $\%$ \\
\hline Seeking information online, shopping online. & 103 & $27 \%$ \\
\hline Seeking information online, shopping in brick-and-mortar store. & 139 & $37 \%$ \\
\hline Seeking information in the brick-and-mortar store, shopping online. & 29 & $7 \%$ \\
\hline $\begin{array}{l}\text { Seeking information in the brick-and-mortar, shopping in the brick-and- } \\
\text { mortar store. }\end{array}$ & 109 & $29 \%$ \\
\hline
\end{tabular}


Also the process of seeking information and convenient shopping place was examined in our research. Surprisingly, Generation Y individuals use very similarly online and offline environment. However, online seeking of information is typical for this Generation. Nearly $64 \%$ of them start their shopping process with searching information online. Surprisingly, more of them (within this group of those who search information online before purchase) finish their shopping process offline, i.e. in a brick-and-mortar store.

The highest share of all respondents prefers online searching of information with follow-up purchase in a brick-and-mortar store (nearly $37 \%$, see Tab. 5). On the other hand, completely online shopping process is the best choice for approx. $27 \%$ of Generation Y. Surprisingly; even more people in this generation (nearly $29 \%$ ) search information and also shop offline, i.e. in the brick-and-mortar stores.

Only one statistically significant difference was found regarding to the gender or country of origin of the respondents. All other attitudes, except of those presented below in this chapter, are general and applicable on the Generation $\mathrm{Y}$ as one homogenous unit.

Men much more prefer pure online shopping, i.e. online searching of information as well as final online purchase $(\operatorname{men}=38 \%$, women $=20 \%$ ). The preference of combination of online seeking of information and purchase in the brick-and-mortar store as well as the combination of searching information offline and online purchase is almost equal by both genders. On the other hand, women in contrast with men prefer much more pure offline shopping process, i.e. both searching information and purchase offline. These differences are statistically significant $\left(\chi^{2}=24.947\right.$, sig. 0.000$)$.

\subsection{Attitudes of Generation $Y$ to Shopping, Discount and Sales}

Generation Y individuals can always find the suitable place for shopping and prefer well-known shops more. The preference of well-known stores was also proven in the category of online shops. These well-known retailers are considered to offer a good quality of products, especially by men (mean=3.2, $\eta=0.108$, sig. 0.006). But on the other hand, a particular name of the retailer is not deemed as important. This statement can be more applied in the Czech Republic (mean $=4.2, \eta=0.146$, sig. $=0.004$ ) and in the group of men (mean $=4.2, \eta=0.134$, sig. $=0.035$ ).

People, especially women (mean $=2.4, \eta=0.127$, sig. $=0.013$ ) in this generation tend to have several favorite shops where they always make their purchases. Also verified shops are more preferred to make purchase in. Generation Y members consider themselves to be the excellent shoppers. This tendency is more present in the Czech Republic than in Slovakia (mean=3.1, $\eta=0.110$, sig. $=0.032$ ). Together with perception of excellence in the process of shopping, they deem themselves more as innovators.

Generation Y individuals do not have problems with online shopping and are not afraid to shop online while men perceive both as less problematic (no problems with online shopping: mean $=2.2, \eta=0.167$, sig. $=0.001$; fear of shopping: mean $=5.3, \eta=0.112$, sig. $=0.029$ ).

Online shopping is considered to be faster than shopping in the brick-and-mortar stores, again more by men (mean $=3.3, \eta=0.140$, sig. $=0.009$ ). Sometimes an overloading by a width of assortment can appear in this generation which then leads to the confusion by the process of choosing 
the best shopping place. Then maybe the help of salespeople can be accepted, i.e. personalized approach to the customer.

The sales promotion activities in the stores are well appreciated by Generation Y. The most average evaluation (total mean=4.2), i.e. close to the middle of the scale, has appeared in the statement 'I regularly browse leaflets with sales offers'. The ambiguous attitude can indicate that there exist one group of those who browse leaflets and another group of those who have negative attitude to leaflets with special discounts usually offered by retail chains. This assumption was confirmed, women regularly browse leaflets more often than men (mean $=3.8, \eta=0.203$, sig. $=0.000)$. They also admit higher influence of special offers and discounts on their shopping decisions $($ mean $=2.8, \eta=0.200$, sig. $=0.000)$.

Purchase with a special discount or with the usage of a special coupon makes this generation happy. They have no problem to use coupons in the retail store and they admit coupon usage in order to save money, even if they are accompanied by friends. Strong disagreement has appeared in the statement 'If my friends see me buying with coupons, my reputation would fall down'. Women show much more positive attitude to various special discounts and sales then men. These differences are also statistically significant, but the strengths of dependences are low ( $\eta$ not higher than 0.219 in all examined statements). Generation Y individuals do not have clear opinion to the loyalty cards and their usage (mean value oscillate around the middle of the scale used in the questionnaire). If not mentioned above, no other statistically significant differences have appeared.

\subsection{Attitudes of Generation Y to Brands and Retailers}

Research results suggest a discrepancy in the perception of brands by Generation Y. On one hand, brands are perceived as the symbol of quality and its guarantee. When these people shop online, they prefer well-known brands. But on the other side, the price image of brands is not good, brands are supposed to be uselessly expensive in the eyes of Generation Y individuals.

Generation Y individuals claim that they do not feel judged by others according to the products they buy. As well as they do not admire others because of owning expensive cars or houses. Brands are not symbols of prestige or success.

Men seem to be more 'brand-addicted' than women. Statistically significant differences have appeared in the perception of brands as the guarantors of quality (mean by men $=2.8, \eta=0.131$, sig. $=0.010)$ and in the perception of expensive properties as reasons why to admire other people (mean by men=4.6, $\eta=0.111$, sig. $=0.031$ ). In this statement also Slovaks (stronger disagreement, mean=5.2) differ from Czechs significantly (mean=4.5, $\eta=0.170$, sig. $=0.001$ ). Although some statistically significant differences exist between groups within the Generation $\mathrm{Y}$, the strength of dependences is in many cases very low.

\subsection{Factor Analysis of Attitudes to Shopping, Brands and Discounts}

Factor analysis was conducted in order to find some similarities in the evaluation of particular statements by the respondents. All the statements from chapters 4.4 and 4.5 were included. Due to the results of Kaiser-Meyer-Olkin measure of sampling adequacy (KMO measure=0.662) and 
significance of Bartlett's test of sphericity (sig.=0.000), factor analysis is well applicable to the data and valid.

Statements were divided into 4 main groups (see Tab. 6). These new factors can be further used for segmentation of Generation Y according to their attitudes to shopping, brands, retailers and discounts.

The first group can be named as 'Brand and tradition loving'. Statements included in the first factor comprise attitudes associated with positive point of view to the branded products and verified stores. Branded products are symbols of success and prestige. Possession of expensive houses, cars or other property may be the reason to admire other people. Impressing others with owned property is positively perceived. On the other hand, people feel judged by others according to things they possess. Well-known retailers or brands can be seen as equivalents of good quality. As well as the name of the retailer is important. Extra money paid for brands are worth of it. Coupons are considered to be inferior and are not used. Innovations are not needed.

Tab. 6 - Factor Analysis of All Attitudes to Shopping, Brands and Discounts. Source: Author's Own.

\begin{tabular}{|l|c|c|c|c|}
\hline Rotated Component Matrix & 1 & 2 & 3 & 4 \\
\hline Branded product = symbol of success and prestige. & 0.687 & & & \\
\hline I admire people that own expensive house, car, jewelry. & 0.585 & & & \\
\hline Well-known retailer is an equivalent to a good quality. & 0.562 & & & \\
\hline I have only several favorite brands that I buy. & 0.56 & & & \\
\hline People judge me according to products I usually buy. & 0.551 & & & \\
\hline I like to own things that impress others. & 0.549 & & & \\
\hline The name of the retailer is important for me. & 0.524 & & & \\
\hline Brand is a guarantee of quality. & 0.495 & & & \\
\hline Coupons are inferior. & 0.435 & & & \\
\hline I would never buy anything with a coupon. & 0.402 & & & \\
\hline Brands are uselessly expensive. & -0.382 & & & \\
\hline I am not an innovator. & 0.334 & & & \\
\hline I prefer stores with a personalized approach & & & & \\
to customer. & & & & \\
\hline I have no problem with shopping online. & & 0.678 & & \\
\hline I can always choose suitable shopping place. & & 0.626 & & \\
\hline I am afraid to shop online. & & -0.565 & & \\
\hline I like to shop in well-known shops. & & 0.513 & & \\
\hline I think I am an excellent shopper. & & 0.472 & & \\
\hline When I shop online, I prefer well-known brands. & & 0.439 & & \\
\hline If my friends see with coupons, my reputation falls. & & & \\
\hline Online shopping is faster than offline. & & & \\
\hline
\end{tabular}




\begin{tabular}{|c|c|c|c|}
\hline I have several favorite stores where I always shop. & 0.42 & & \\
\hline When I shop online, I prefer well-known shops. & 0.416 & & \\
\hline I prefer verified shops. & 0.314 & & \\
\hline When I buy in sales, I am happy to save some money. & & 0.774 & \\
\hline I use coupons to save money. & & 0.762 & \\
\hline Sales inspire me to shop. & & 0.656 & \\
\hline I regularly browse leaflets with sales offers. & & 0.568 & \\
\hline I always use my loyalty card, if it is possible. & & 0.357 & \\
\hline $\begin{array}{l}\text { The more I look for shopping place, the more I am } \\
\text { confused. }\end{array}$ & & & 0.704 \\
\hline $\begin{array}{l}\text { Information about retailer does not help me to make } \\
\text { choice. }\end{array}$ & & & 0.631 \\
\hline It is a problem to choose where I make my purchase. & & & 0.604 \\
\hline I sometimes feel overloaded by the width of supply. & & & 0.566 \\
\hline
\end{tabular}

The second factor consists of statements which refer to the impression of easy shopping as well as verifying information available. The simplicity of choosing the appropriate shopping place can lead to the impression of being the excellent shopper. Online shopping costs less time than shopping in the brick-and-mortar stores. The fear of online shopping is not present. The best suitable shopping place is found easily without any problems. If the shop is well-known or it offers well-known brands, it is well-perceived and preferred. The usage of coupons is not rejected. Therefore the term for the second factor is 'Shopping is easy if you verify information'.

The third factor 'Discount loving' refers to the great passion which is generated by shopping in sales. Discounts can make people happy, induce them to browse leaflets with sales offers regularly and use their loyalty cards whenever it is possible. Saving money is the primary reason to use coupons. Sales can be the inspiration to make purchase.

The fourth factor indicates the frustration created by shopping. The name 'Information and supply overloading' fits the character. The confusion by searching the best suitable shopping place, overloading by the width of supply and not sufficient information about retailers - those are typical statements associated with the last factor. The higher the frequency of searching the best shopping place is, the higher level of frustration comes.

\subsection{Shopping Centers}

Generation $\mathrm{Y}$ individuals spend more than 2 hours in one average visit of the shopping center ( 2 hours and 25 minutes). Women spend more time during one visit ( 2 hours and 40 minutes) in the contrast with men ( 2 hours and 3 minutes). This result is statistically significant, but the strength of dependence is still low $(\eta=0.225$, sig. $=0.000)$. Differences between Czech and Slovak respondents were not observed.

Typical activities in the shopping center are planned purchase (nearly $80 \%$ ), visiting restaurant or fast-food for lunch (45\%) and visiting cinema (39\%). Unplanned purchases are typical for almost $30 \%$ of respondents. 
Men plan their appointments in the shopping centers more often than women $\left(\chi^{2}=6.357\right.$, sig. $=0.011)$. While women more often make unplanned purchases $\left(\chi^{2}=8.099\right.$, sig. $\left.=0.003\right)$ and go for coffee to the shopping center $\left(\chi^{2}=4.530\right.$, sig. $\left.=0.022\right)$ than men. People in Slovakia go for planned purchases to the shopping centers more than Czechs $\left(\chi^{2}=3.853\right.$, sig. $\left.=0.032\right)$ and also plan their appointments more often there $\left(\chi^{2}=4.079\right.$, sig. $\left.=0.035\right)$.

\section{DISCUSSION}

General attitudes of Generation Y individuals were very similar in both countries. Only small differences were found. In the Czech Republic people of this generation more consider themselves to be excellent shoppers and accentuate the importance of well-known retailers which offer the assortment with better quality. Slovaks behave more like individualists and less accentuate the importance of branded products.

Despite of Djamasbi, Siegel and Tullis (2010) results of our research do not indicate total addiction of Generation $\mathrm{Y}$ to the online environment. They in general do not feel cut of information in case they are not online. On the other hand they do not avoid using internet opportunities to stay in touch with the social environment, especially friends. This agrees with Nusair et al. (2013). The communication by social networks is very common. Men are more interested in new technologies emerging in the market, download new applications more often and stay online also at work or outdoor more than women. Factor analysis of these statements led to the distribution of statements into 4 new factors named Always online, Online information, Individuality and New technologies.

Shopping is perceived as a leisure activity, the source of fun and excitement. Our results fit opinion of Bakewell and Mitchell (2006). Women perceive shopping more than men as fun, relax, pleasure and excitement. Browsing in the shop is not as highly welcomed as Bakewell and Mitchell (2006) declare. Generation Y in the Czech Republic and Slovakia probably searches more information before purchase and likes to go straight to buy a particular product. They also realize the necessary purpose of shopping.

One visit of shopping center lasts in average 2 hours and 25 minutes. Generation Y individuals not only shop in the shopping center, they also visit restaurants, go to the cinema, for coffee or arrange appointments there. This supports the results of Gilboa and Vilnai-Yavetz (2010).

Generation Y individuals choose at first a product they would like to buy. The choice of shopping place follows afterwards. This result supports statements of Parment (2013). Information before purchase is mostly searched for in online sources. Surprisingly, the final purchase is then finished more often in offline shops. However, completely offline searching information followed by offline purchase is still the first choice for nearly $29 \%$ of Generation Y individuals, especially women.

The importance of well-known shops in both online and offline environment was also found. People in this generation consider themselves as excellent shoppers and more innovators. Also Mangold and Smith (2012) have the same opinion. Online shopping is considered to be faster and more convenient. They do not have any problems to shop online, especially men. The over- 
loading by the width of supply and information can have the negative effect on the Generation Y shopping behavior.

Brands are considered to be the symbols and guarantors of quality, but also uselessly expensive. The evaluation of brands as symbols of prestige and success did not confirm results of Phau and Cheong (2009) and O'Cass and Siahtiri (2013). On the other hand, discounts and sales offers are positively perceived by Generation Y as well as Ballard et al., (2013) claims. Members of Generation $\mathrm{Y}$ do not feel ashamed when they shop with a coupon even if they are seen by friends.

All attitudes to shopping, brands, retailers and discounts were analyzed with the usage of factor analysis. New factors are as follows Brand and tradition loving, Shopping is easy if you verify information, Discount loving, Information and supply overloading. Due to limited extend of this paper, final segmentation of Generation $\mathrm{Y}$ according to the results of both factor analyzes is not included in this paper.

\section{CONCLUSION}

This paper was focused on the shopping behavior of Generation $\mathrm{Y}$ in the context of the Czech Republic and Slovakia. The main aim was to describe the specifics of Generation Y general behavior associated with online environment and to examine the specifics of shopping behavior regarding to perception of brands, retailers, discounts and sales promotions.

The research in order to gain data for further analysis was conducted in autumn and winter 2014 in the Czech Republic and Slovakia. The online and written questioning was the main method of gaining data. Basic descriptive statistics, analysis of dependence and factor analysis were used as statistical methods to analyze data.

No surprising and big differences between Czech and Slovak members of Generation Y were found. In the Czech Republic people of this generation more consider themselves to be excellent shoppers and accentuate the importance of well-known retailers which offer the assortment with better quality. Slovaks behave more like individualists and less accentuate the importance of branded products.

Generation Y members realize that the usage of online tools can bring them a positive effect. They use social networks very often to communicate and are really interested in new technologies in the market. On the other hand, they do not feel the need to be online everywhere and every time.

Shopping in general is perceived as fun, relax and pleasure, but also as a necessary part of life. Generation Y consider itself to be excellent in shopping and innovative. They spend quite a lot of time in the shopping center in one visit. Purchase is not the only purpose to visit this retail format, also cinema, restaurant of appointments can be the reasons to go to the shopping center.

Shopping behavior is not oriented only to 'online world'. Significant part of this generational cohort searches information offline as well as makes purchases in the brick-and-mortar stores. Men more likely use online sources of information and finish their purchase online. Generation Y members consider online shopping to be faster than shopping in the brick-and-mortar stores. The decision making process starts with the choice of a specific product, the choice of suitable shopping place follows afterwards. 


\section{Acknowledgements}

This paper has been supported from the research project SP2015/118 - Shopping behaviour of Generation Y in the international context on the Faculty of Economics, VSB - Technical university of Ostrava [SP2015/118].

\section{References}

1. Bakewell, C., \& Mitchell, V-W. (2006). Male versus female consumer decision making styles. Journal of Business Research. 59 (12), 1297-1900. http://dx.doi:10.1016/ j.jbusres.2006.09.008

2. Ballard, B. et al. (2013). Relationship Marketing and the Net Generation of Couponers. In Global Conference on Business and Finance Proceedings (pp.403-407). San Jose (Costa Rica): The Institute for Business and Finance Research.

3. Bednall, D., Valos, H., Adam, S.M., \& McLeod, C. (2012). Getting Generation Y to Attend: Friends, Interactivity and Half-time Entertainment. Sport Management Review, 15 (1), 80-90. http://dx.doi:10.1016/j.smr.2011.04.001

4. Bergh van den, J., \& Behrer, M. (2011). How Cool Brands Stay Hot. Branding to Generation Y. London: Kogan Page.

5. Brosdahl, D. J. C., \& Carpenter, J. M. (2011). Shopping orientations of US males: A generational cohort comparison. Journal of Retailing and Consumer Services, 18 (6), 548-554. http://dx.doi:10.1016/j.jretconser.2011.07.005

6. Brosdahl, D. J. C., \& Carpenter, J. M. (2012). U.S. male generational cohorts: Retail format preferences, desired retail attributes, satisfaction and loyalty. Journal of Retailing and Consumer Services, 19 (6), 545-552. http://dx.doi:10.1016/j.jretconser.2012.06.005

7. Carr, A., \& Ly, P. (2009). "More than words": Screencasting as a reference tool. Reference Services Review, 9 (37), 408-420. http://dx.doi.org/10.1108/00907320911007010

8. Dhanapal, S., Vashu, D., \& Subramaniam, T. (2015). Perceptions on the challenges of online purchasing: a study from "baby boomers", generation " $\mathrm{X}$ " and generation "Y" point of views. Contaduria y Administración, 60 (1), 107-132. http://dx.doi:10.1016/j.cya.2015.08.003

9. Djamasbi, S., Siegel, M., \& Tullis, T. (2010). Generation Y, web design, and eye tracking. International Journal of Human-Computer Studies, 68 (5), 307-323. http://dx.doi:10.1016/ j.ijhcs.2009.12.006

10. Eastman, J.K., \& Liu, J. (2012). The impact of generational cohorts on status consumption: an exploratory look at generational cohort and demographics on status consumption. Journal of Consumer Marketing, 29 (2), 93-102. http://dx.doi:10.1108/07363761211206348

11. Gilboa, S., \& Vilnai-Yavetz, I. (2010). Four generations of mall visitors in Israel: A study of mall activities, visiting patterns, and products purchased. Journal of Retailing and Consumer Services, 17 (6), 501-511. http://dx.doi:10.1016/j.jretconser.2010.08.005

12. Haytko, D., \& Baker, J. (2004). It's all at the mall: exploring adolescent girls' experiences. Journal of Retailing, 80 (1), 67-83. http://dx.doi:10.1016/j.jretai.2004.01.005

13. Horáková, M. (2015). Consumer Behavior of College Students in the Czech Republic. Journal of Competitiveness, 7 (4), 68-85. http://dx.doi.org/10.7441/joc.2015.04.05 
14. Jain, V., \& Pant, S. (2012). Navigating Generation Y for Effective Mobile Marketing in India: A Conceptual Framework. International Journal of Mobile Marketing, 7 (3), 56-65.

15. Kim, D., \& Jang, S. (2014). Motivational drivers for status consumption: A study of Generation Y consumers. International Journal of Hospitality Management, 38 (1), 39-47. http:// dx.doi:10.1016/j.ijhm.2013.12.003

16. Mandhlazi, L., Dhurup, M., \& Mafini, CH. (2013). Generation Y Consumer Shopping Styles: Evidence from South Africa. Mediterranean Journal of Social Sciences, 4(14), 153-164. http://dx.doi.org/10.5901/mjss.2013.v4n14p153

17. Mangold, W. G., \& Smith, K. T. (2012). Selling to Millennials with Online Reviews. Business Horizons, 55 (2), 141-153. http://dx.doi:10.1016/j.bushor.2011.11.001

18. Martin, C.A., \& Turley L.W. (2004). Malls and consumption motivation: an exploratory examination of older generation Y consumers. International Journal of Retail \& Distribution Management, 32 (10), 464-75. http://dx.doi.org/10.1108/09590550410558608

19. Miller, K., \& Mills, M. (2012). Fashion Marketing and Consumption of Luxury Brands. Journal of Business Research, 65 (10), 1471-1479. http://dx.doi:10.1016/j.jbusres.2011.10.013

20. Noble, M. S., Haytko, D. L., \& Phillips, J. (2009). What Drives College-age Generation Y consumers? Journal of Business Research, 62 (6), 617-628. http://dx.doi:10.1016/ j.jbusres.2008.01.020

21. Nusair, K. et al. (2013). Generation Y travelers' commitment to online social network websites. Tourism Management, 35 (1), 13-22. http://dx.doi:10.1016/j.tourman.2012.05.005

22. O'Cass, A., \& Siahtiri, V. (2013). In search of status through brands from Western and Asian origins: Examining the changing face of fashion clothing consumption in Chinese young adults. Journal of Retailing and Consumer Services, 20 (6), 505-515. http://dx.doi:10.1016/ j.jretconser.2013.05.005

23. Omnicom Media Group (OMG). (2011). OMG Proprietary Millennials Study. Retrieved May 15, 2015, from http://www.phdmedia.com/getattachment/Thought-Leadership/MediaCloser-Look/Articles/Millenials/Millennials-A-Global-Generation.pdf.aspx.

24. Parment, A. (2013). Generation Y vs. Baby Boomers: Shopping Behavior, Buyer Involvement and Implication for Retailing. Journal of Retailing and Consumer Services, 20 (2), 189-199. http://dx.doi:10.1016/j.jretconser.2012.12.001

25. Pentecost, R., \& Andrews, L. (2010). Fashion Retailing and the Bottom Line: The Effects of Generational Cohorts, Gender, Fashion Fanship, Attitudes and Impulse Buying on Fashion Expenditure. Journal of Retailing and Consumer Services, 17 (1), 43-52. http:// dx.doi:10.1016/j.jretconser.2009.09.003

26. Phau, I., \& Cheong, E. (2009). How Young Adult Consumers Evaluate Diffusion Brands: Effects of Brand Loyalty and Status Consumption. Journal of International Consumer Marketing, 21 (2), 109-123, http://dx.doi:10.1080/08961530802153185

27. Sox, C. B., Kline, S. F., \& Crews, T. B. (2014). Identifying best practices, opportunities and barriers in meeting planning for Generation Y. International Journal of Hospitality Management, 36 (1), 244-254. http://dx.doi:10.1016/j.ijhm.2013.09.009 
28. Varutti, P. (2011). Jací jsou dnešní mladí?. Retrieved January 25, 2015, from http://www. mediaguru.cz/2011/11/jaci-jsou-dnesni-mladi/\#.

29. Weiler, A. (2005). Information-Seeking Behavior in Generation Y Students: Motivation, Critical Thinking, and Learning Theory. The Journal of Academic Librarianship, 31 (1), $46-$ 5Audretsch, D.B., \& Feldman, M. (1996). Innovative Clusters and the Industry Life Cycle. Review of Industrial Organization, 11 (2), 253-273. http://dx.doi.org/10.1007/BF00157670

\section{Contact information}

Ing. Petra Klapilová Krbová, Ph.D.

VSB - Technical University of Ostrava, Faculty of Economics, Department of Marketing and Business Sokolská trída 33, 70121 Ostrava 1, Czech Republic

E-mail:petra.klapilova@vsb.cz. 